\title{
Clinical Features of a Pediatric Case with Cone
}

\section{Dystrophy}

\section{Kon Distrofili Pediatrik Bir Olgunun Klinik Özellikleri}

\author{
Lokman Balyen $^{1^{\star}}$, Tuncay Küsbeci ${ }^{2}$ \\ ${ }^{1}$ Kafkas Üniversitesi Tip Fakültesi, Göz. Hastalıklarn Ana Bilim Dal, Kars \\ ${ }^{2}$ Bozyaka Eğitim ve Arastırma Hastanesi, Göz. Hastalıları Kliniği, İzmir
}

\begin{abstract}
The cone dystrophy is a nonhomogenous group of inherited and progressive retinal diseases that affects chiefly the cone system. It is frequently characterized by progressive loss of visual acuity, photophobia, central scotoma, color vision disturbances, and morphologic macular changes together with low response or unresponsiveness in photopic electroretinography (ERG). A girl, 9 years of age, presented with progressive visual loss, photophobia, and falling school performance. ERG revealed severe cone dysfunction with both cone and cone flicker responses (photopic) in both eyes. However, rod and rod-cone combined responses (scotopic) were evaluated at normal limits in both eyes. Fundus photography, colour vision testing, fundus autofluorescence, optical coherence tomography, ERG, visual evoked potential (VEP), Sweep VEP were performed the patient. This case report may provide clinical and diagnostic information for clinicians and may contribute to a better understanding of cone dystrophies in clinical practice. The diagnosis of cone dystrophies should be done with careful anamnesis and detailed ophthalmologic examination. With early diagnosis, there is a chance of early rehabilitation. Low vision rehabilitation is very significant because of the progressive nature of this disease, the lack of effective treatment, and the fact that the vision of the patients during the active term of school and working life are drastically affected. This case report shows that ERG can be used as a quite beneficial clinical test in terms of early and differential diagnosis of cone dystrophies.
\end{abstract}

Key Words: Retinal degeneration, cone-rod dystrophies, visual impairment, electroretinography

\section{Introduction}

The cone dystrophy is a nonhomogenous group of inherited and progressive retinal diseases that affects chiefly the cone system $(1,2,3)$. However, the involvement of rod system is relatively more

\begin{abstract}
ÖZET
Kon distrofisi, öncelikle kon sisteminin işlevini etkileyen, kalitsal ve ilerleyici retinal bozukluklarin heterojen bir grubudur. Fotopik elektroretinografide (ERG) düşük yanıt veya yanıt vermeme ile birlikte ilerleyici görme keskinliği kaybı, renkli görme bozukluğu, fotofobi, merkezi skotom ve morfolojik maküler değişiklikler ile sıklıkla karakterizedir. 9 yaşındaki bir hasta ilerleyici görme kayb1, fotobobi ve okul performansinda azalma ile başvurdu. ERG, her iki gözün kon ve kon flicker yanıtlarında (fotopik) ciddi kon işlev bozukluğunu ortaya çıkardı. Bununla birlikte her iki gözün rod ve rod-kon kombine yanitları (skotopik) normal sinırlarda değerlendirildi. Hastaya fundus fotoğrafı, renkli görme testi, fundus autofluoresan, optik koherens tomografi, ERG, görsel uyarılmış potansiyel (VEP), Sweep VEP uyguland. $\mathrm{Bu}$ vaka raporu klinisyenler için klinik ve diagnostik bilgileri sağlayabilir ve klinik uygulamada kon distrofilerinin daha iyi anlaşılmasına katkıda bulunabilir. Kon distrofilerin tanisı dikkatli anamnez ve detaylı oftalmolojik muayene ile yapılmalıdır. Erken tanı ile erken rehabilitasyon şansı vardır. Düşük görme rehabilitasyonu, bu hastalığın ilerleyici doğası, etkili tedavinin olmaması ve aktif okul ve çalışma hayat1 boyunca hastaların vizyonunun büyük ölçüde etkilenmesi nedeniyle çok önemlidir. Bu olgu sunumu, ERG'nin kon distrofilerinin erken ve ayırıcı tanısında en yararlı klinik test olduğunu göstermektedir.
\end{abstract}

Anahtar Kelimeler: Retinal dejenerasyon, kon-rod distrofileri, görme bozukluğu, elektroretinografi

restricted. It is characterized by progressive impairment of visual acuity, central scotoma, photophobia, sensitivity to glare, nystagmus, color vision disturbances, and morphologic macular changes together with low response or unresponsiveness in photopic electroretinography 
A

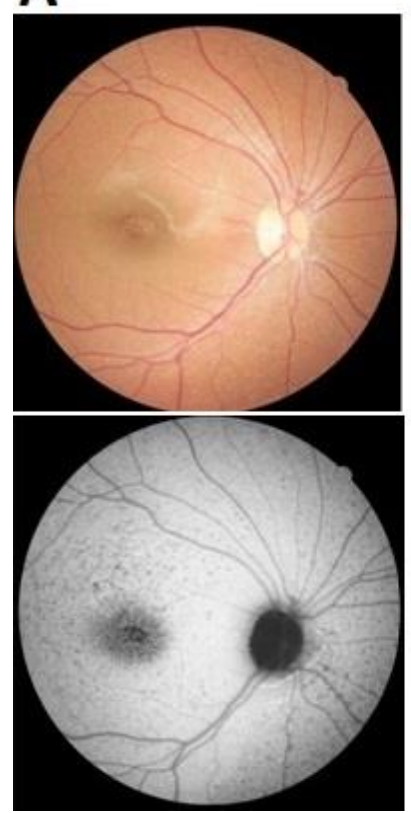

B

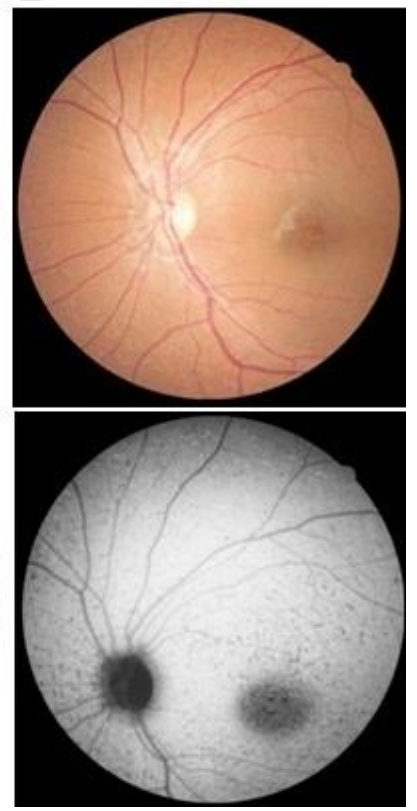

Fig. 1. Color fundus examination shows retinal pigment epithelium irregularity and atrophy (bull's eye lesion) at the bilateral macula central. Fundus autofluorescence examination reveals hypofluorescence appearance in the areas corresponding to bull's eye maculopathy area in the bilateral macula central, hypofluorescent spots widely distributed in the posterior pole, and hyperfluorescent spots in the midperiphery retina. A: Right eye. B: Left eye

(ERG) (4). Frankly, it may be also stationary as well as progressive form. Besides, the cone dystrophies oughtn't to be confused with congenital color blindness where there are no the degeneration in retina, the loss of visual acuity, and the signs of progressive disease (5). The onset of the symptoms may vary from early childhood to fifties years old, but the vast majority of cases arise in the first twenty years of life. An important

\section{A}

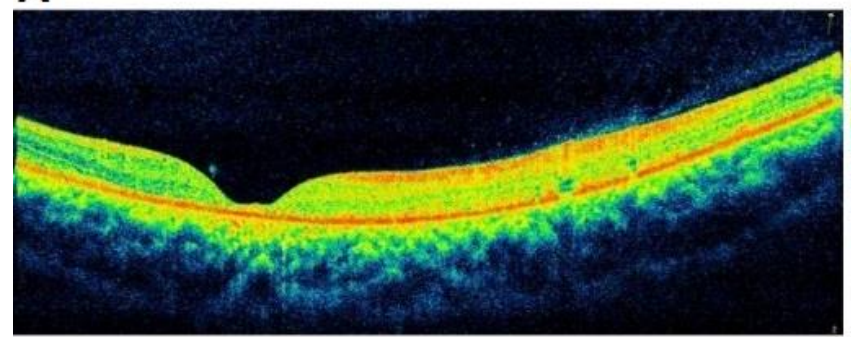

B

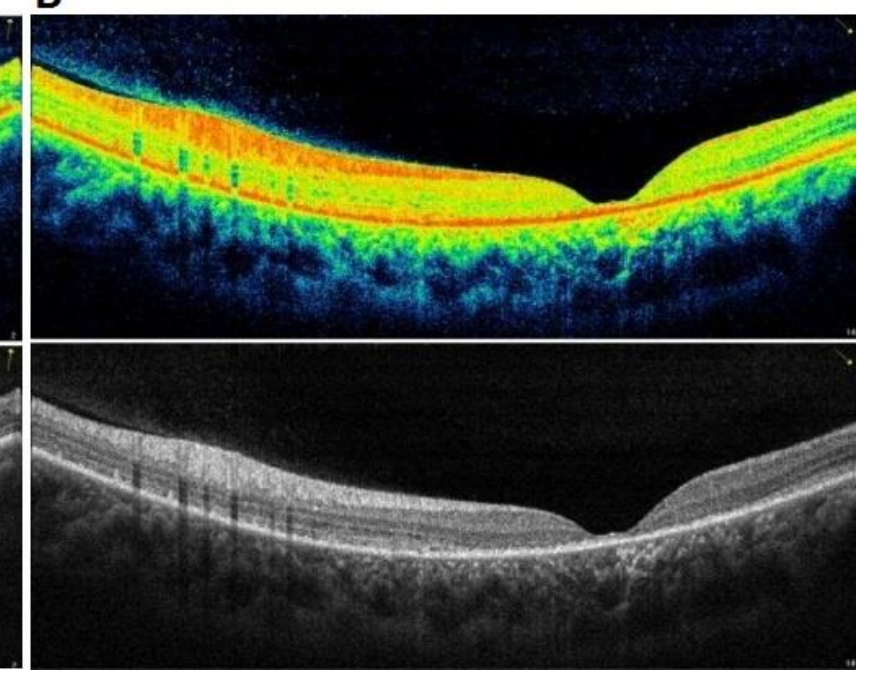

part of cone dystrophies has an autosomal dominant trait, however sometimes may have a $\mathrm{x}$ linked or autosomal recessive trait $(1,5,6)$. Conerod dystrophies (CRDs) are very rare and have approximately a prevalence of $1 / 40000$ (4). Characteristically, fundus changes limited to the macular area include patchy macular spot, a bull's eye lesion, or more prevalent atrophic alterations. However, it is more possible that most patients do not demonstrate any retina abnormalities at the onset of symptoms. It is reported that color vision disturbances are usually red-green type in the early stages $(5,7)$.

We aimed to evaluate the clinical features of a pediatric case with cone dystrophy, which showed a progressive decrease in visual acuity and a drop in school achievement.

\section{Case Report}

A 9-year-old girl applied to the ophthalmology clinic due to progressive visual loss, photophobia, abnormal color vision, and falling school performance was reported. There were no night vision problem, complaints of general diseases, and drug use story in the anamnesis of the patient. Also, the family history regarding ocular diseases wasn't existent. On the ophthalmic examination, the patient's best corrected visual acuity was measured 20/200 with $-0.25 \mathrm{D}$ in both eyes (OU) on Snellen charts. Ocular motility testing was normal. Pupils were equally round and reactive, with no evidence of afferent defect. The anterior segment examinations of both eyes were completely unremarkable. Intraocular pressure was

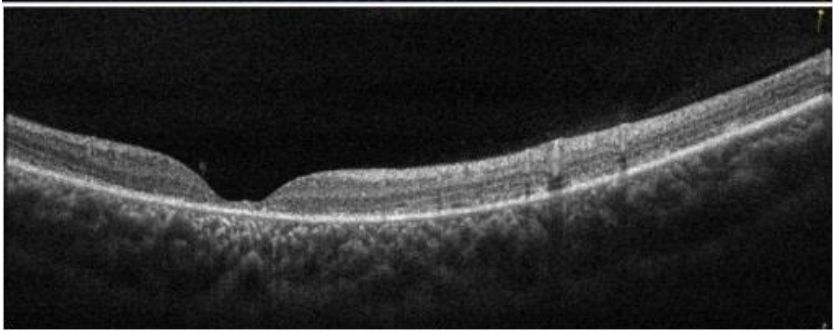

Fig. 2. Optical coherence tomography (OCT) examination shows the thinning of the central macula. Furthermore, the outer layers of the retina in the parafoveal area are markedly thinned. A: Right eye. B: Left eye 
VISUAL ELECTROPHYSIOLOGY EXAM

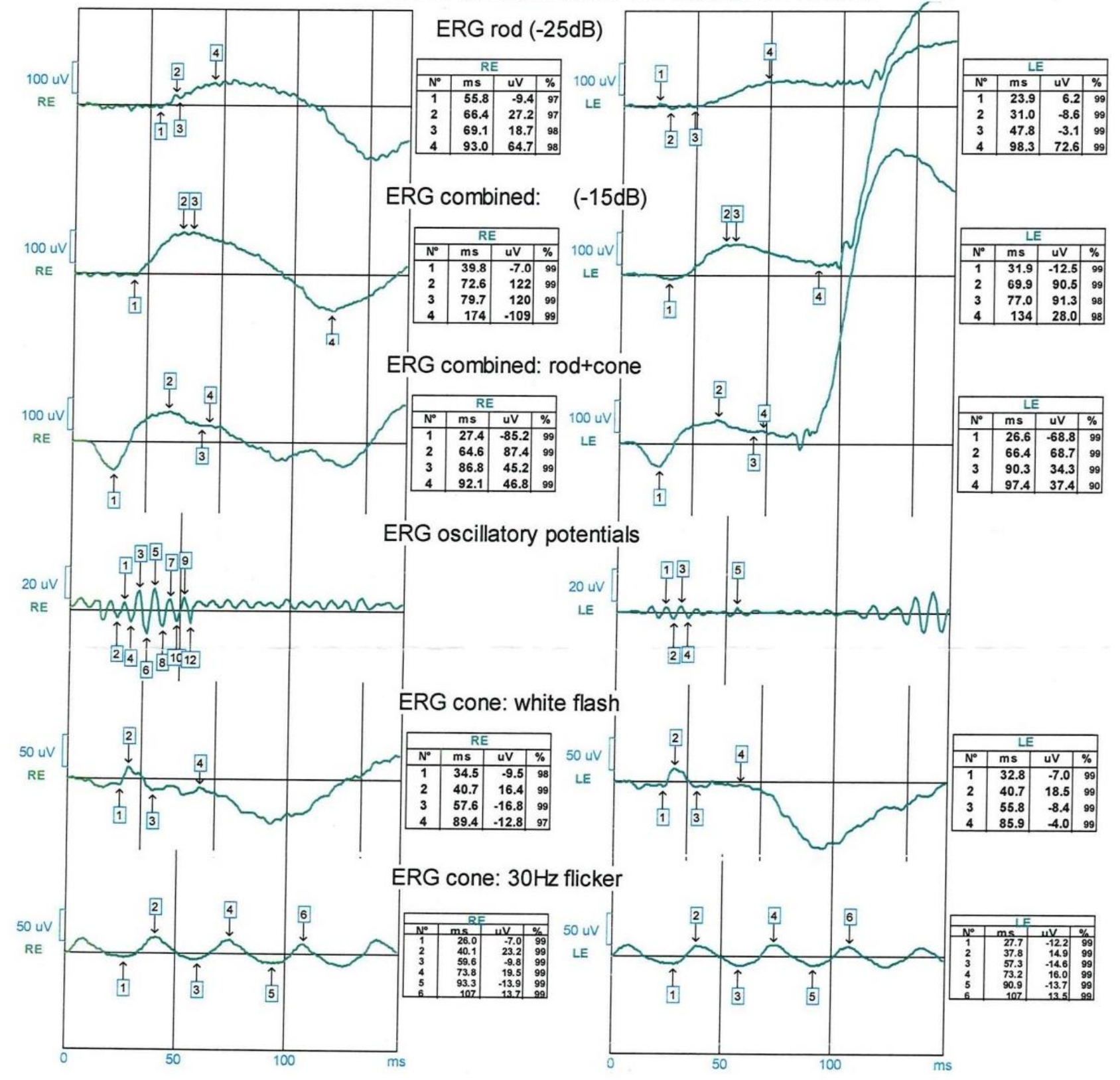

Fig. 3. Electroretinography shows that rod and rod-cone combined responses (scotopic) are bilaterally at normal limits; but, cone and cone flicker responses (photopic) are markedly depressed in the left eye and decreased in the right eye

measured as $12 \mathrm{~mm} \mathrm{Hg}$ OU. Abnormal color vision was detected in both eyes by Ishihara test. Retinal pigment epithelium irregularity and atrophy defined as bull's eye lesion at the bilateral macula central were observed on the color fundus examination (Fig 1). Hypofluorescence appearance in the areas corresponding to bull's eye maculopathy area in the bilateral macula central, hypofluorescent spots widely distributed in the posterior pole, and hyperfluorescent spots in the midperiphery retina were seen on the fundus autofluorescence (FAF) examination (Fig 1). On optical coherence tomography examination, the thickness of the central macula was 155 micrometer in the right eye and 115 micrometer in the left eye. Furthermore, the outer layers of the retina in the parafoveal area were markedly thinned and faded, whereas the outer layers of the retina were not observed in the foveal area. (Fig $2)$. On the ERG, rod and rod-cone combined responses (scotopic, ERG $25 \mathrm{~dB}$, ERG $15 \mathrm{~dB}$ ) were evaluated bilaterally at normal limits; while cone and cone flicker responses (photopic) were recorded markedly depressed in the left eye and decreased in the right eye (Fig 3). On visual evoked potential (VEP) record, with stimuli of 
Balyen ve Küsbeci / A Pediatric Case with Cone Dystrophy

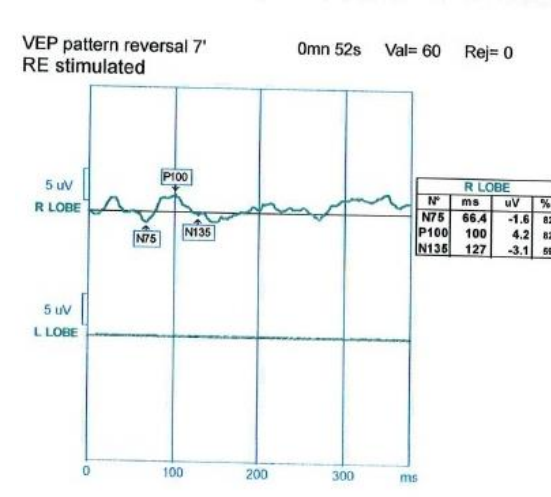

VISUAL ELECTROPHYSIOLOGY EXAM

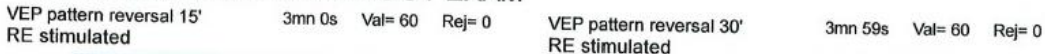
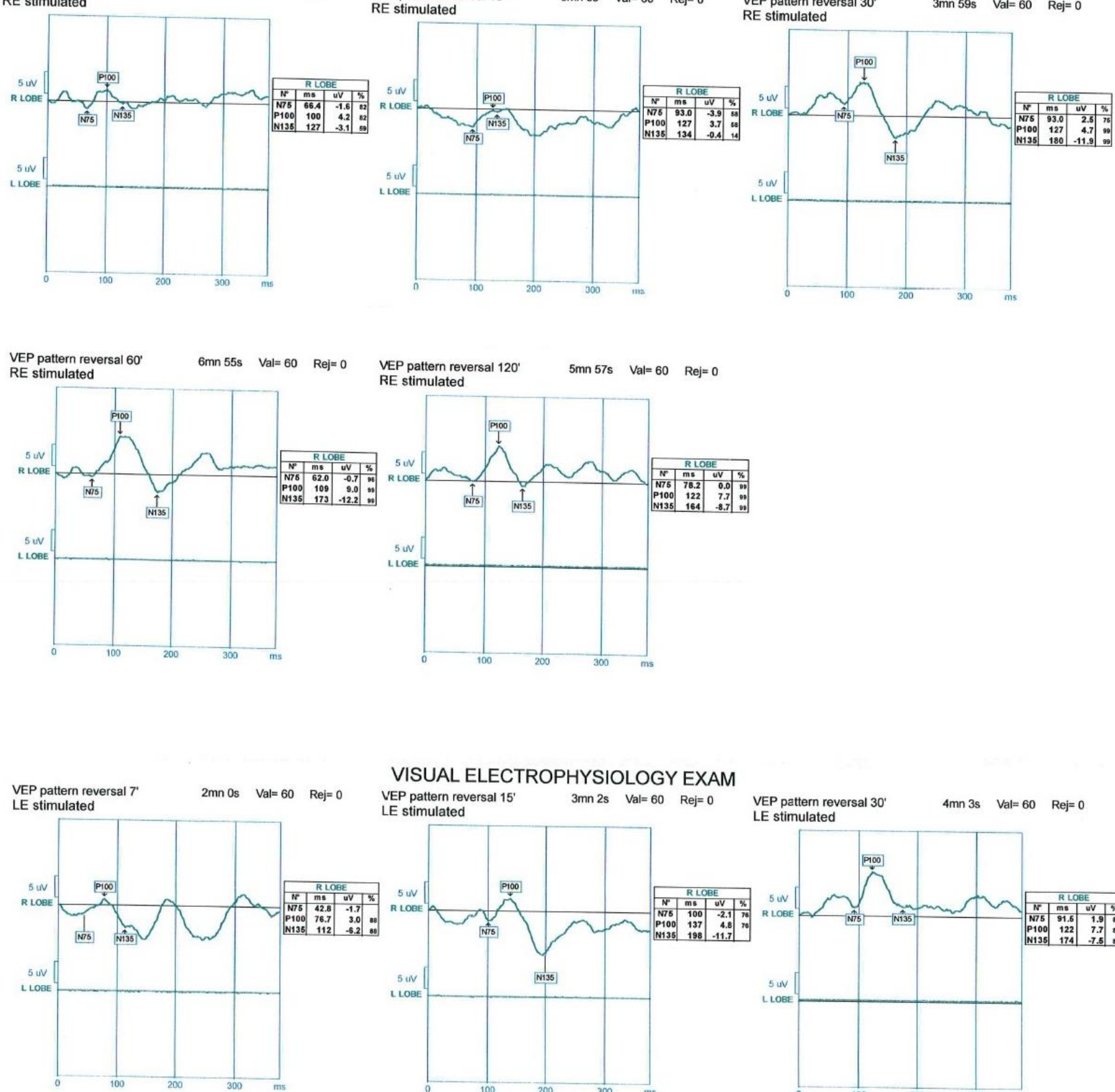

VISUAL ELECTROPHYSIOLOGY EXAM \begin{tabular}{l}
$\begin{array}{l}\text { VEP pattern reversal 15' } \\
\text { LE stimulated }\end{array}$ \\
\hline
\end{tabular}
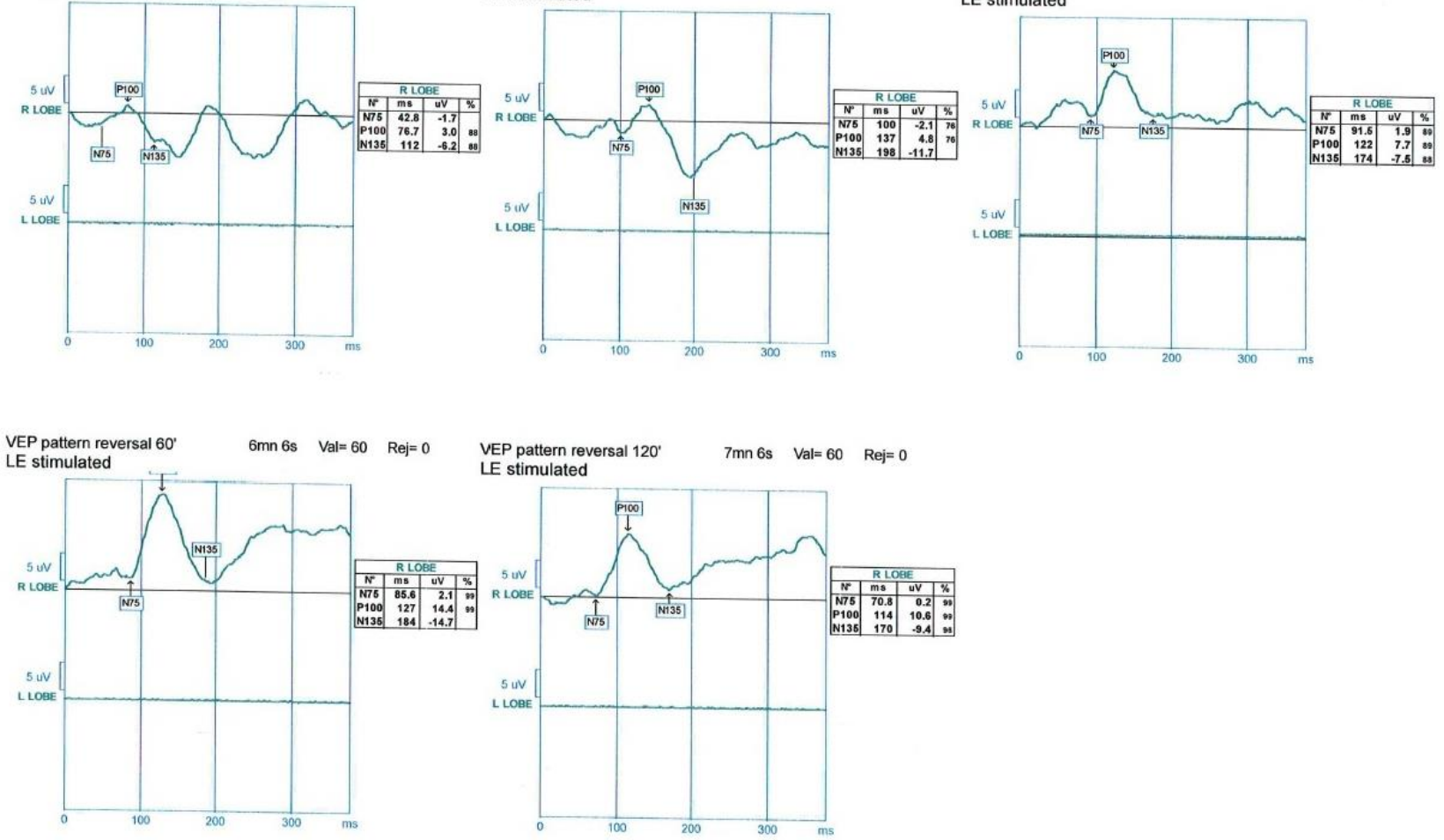

Fig. 4. Visual evoked potential (VEP) reveals the latency and the amplitude of p100 wave

Van Tip Derg Cilt:25, Sayı:4, Ekim/2018 

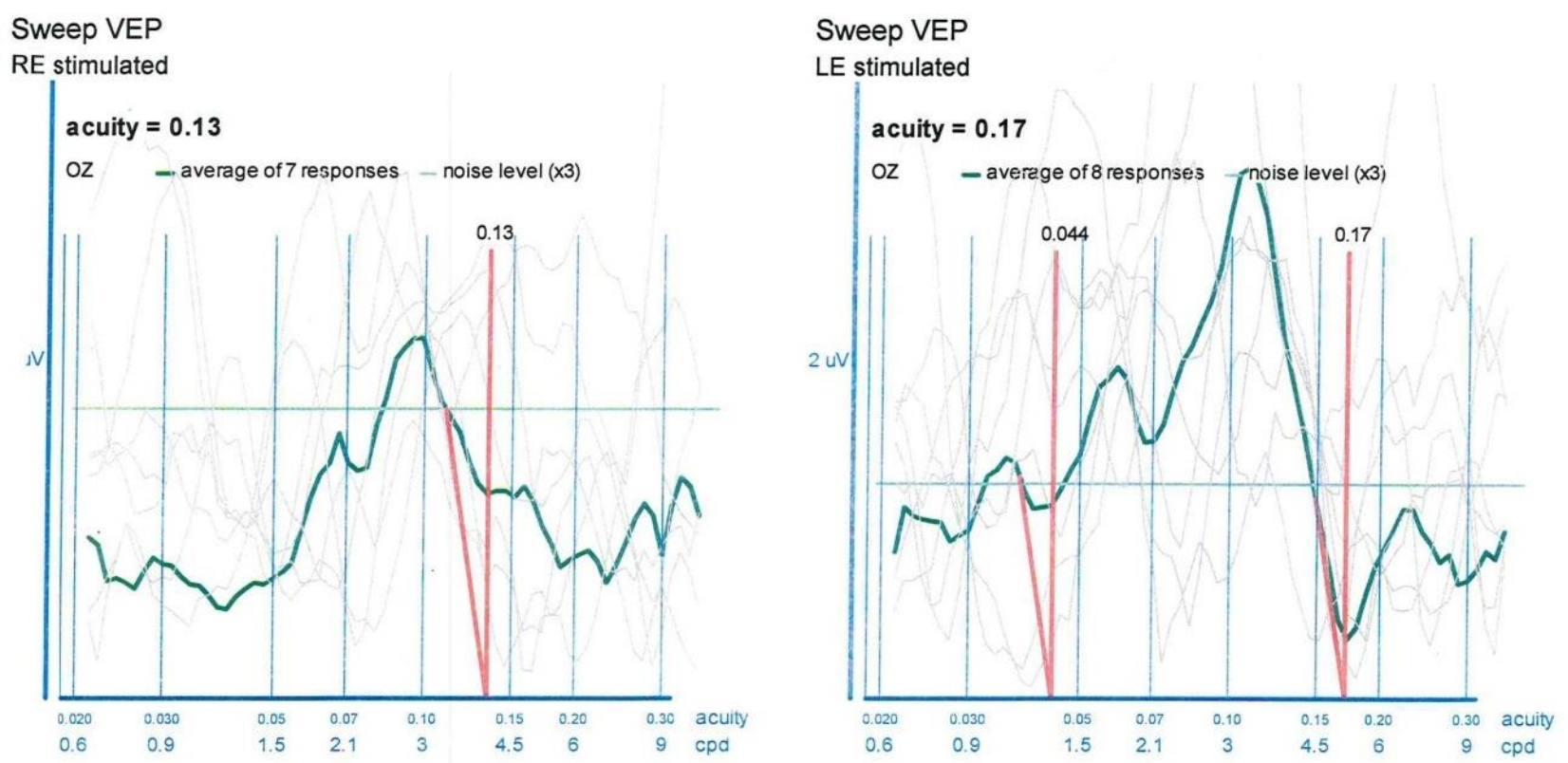

Fig. 5. Sweep VEP examination elicits mean visual acuities in both eyes

pattern 7 and 15 minutes, normal p100 wave could not be recorded. The latency and the amplitude of p100 wave obtained from 30-minute pattern stimulus were $122 \mathrm{msec}$ and $7.7 \mathrm{mV}$, respectively. Whereas, the latency and the amplitude of p100 wave obtained from 60 -minute pattern stimulus were $127 \mathrm{msec}$ and $14.4 \mathrm{mV}$, respectively (Fig 4). On sweep VEP examination, mean visual acuity in the right eye was 0.13 decimal, and the left one was 0.17 decimal (Fig 5). Orbital and brain MRI were normal. In laboratory tests; blood glucose level, liver and kidney function tests, triglyceride, total cholesterol, electrolytes, thyroid function tests, and urinalysis were found to be normal. Audiologic examination showed no hearing loss. Ultrasonography and electrocardiography were normal. The case was followed by ophthalmology and pediatric clinics.

\section{Discussion}

The cone dysfunction syndromes are a genetically and clinically nonhomogenous group of retinal disorders $(1,2,3)$. The cone dysfunction syndromes are seen quite rarely and have not been enlightened in detail yet in terms of pathophysiological. We describe a girl with a cone dystrophy by characterized loss of visual acuity, a bull's eye lesion in the macula, decrease and absent of photopic ERG, photophobia, and lack of colour vision. In this report, the most notable findings were progressive loss of visual acuity, thinning of the retina, and abnormal photopic ERG flicker function. ERG revealed that photopic response was markedly depressed in the left eye and was decreased the amplitudes in the right eye. However, scotopic response was normal in the both eyes. The symptoms of the cone dystrophy are unspecific and subjective and moreover characteristic ophthalmoscopic findings for this disease don't exist, so its diagnosis is quite difficult. Cone dystrophy should be considered in the differential diagnosis of visual loss and therefore either a full-field or multifocal ERG may be necessary in order to explain the issue in such situations. In cases with cone dystrophy, visual acuity is usually better in the early stages of life, and a progressive and dramatic decline can be observed in later ages. The progression of the cone disease symptoms occurs in a symmetrical manner and experiencing symptoms are parallel in both eyes. Besides, photophobia, color vision impairment, better visual acuity in the dark, and central scotoma may be seen. Visual acuity, central visual field, and colored vision become compromised due to the progressive degeneration of the cone photoreceptor cells in the retina. Maculopathy defined as bull's eye lesion at the macula central, retinal pigment epithelial irregularity, and atrophy appearance are usually normal at onset of life. There are other diseases that cause bull's eye maculopathy, such as chloroquine maculopathy, Stargardt's disease, Batten's disease, benign concentric anomalous dystrophy, fenestrated macular dystrophy, and other photoreceptor degenerations $(6,8)$.

ERG test is the most beneficial clinical test in early and differential diagnosis of cone 
dystrophies (3, 9). Also, in the assessment of dystrophic retinal disorders, FAF, a non-invasive retinal imaging technique, is quite advantageous $(3,10)$. The prognosis varies depending on the severity of the rod involvement, and a better prognosis is seen in cases with minimal rod involvement. Unfortunately, there is no specific treatment for cone dysfunction syndrome nowadays. Nevertheless, it is of utmost importance to make a correct diagnosis in order to give accurate information about the prognosis and to provide informed genetic counseling. Although there is no particular treatment, refractive errors can be corrected with appropriate spectacle, patients with low vision may take aids such as magnifiers, software for computer screen text enlargement, and closed-circuit television devices, and special educational assistance may be given. Photophobia is frequently a major symptom in the cone dystrophy and therefore dark sunglasses, contact lenses or miotics may be used in order to enhance the quality of life and vision. Low vision rehabilitation is very important because of the progressive nature of this disease, the lack of effective treatment, and the fact that the vision of the patients during the active periods of school and working life are severely affected. Briefly, with early diagnosis, there is a chance of early rehabilitation $(6,11)$.

Moreover, the beta-carotenoids, omega-3 fatty acids, lutein, zeaxanthin, and foods with low glycemic index have been proved to reduce progression of advanced age-related macular degeneration, and thus the consumption of these supplements may have similar advantages for cone dystrophies. Psychological support is of great importance. Consequently, in hereditary retinal dystrophies such as cone distrophy, the residual vision of patients should be optimally protected to facilitate their daily lives and to support their psychological health (12). In conclusion, cone dystrophies are seen as quite rare. The diagnosis of this rare disease can be difficult, so it is very important that the physicians be careful. This case report may provide clinical and diagnostic information for clinicians, and may contribute to better understanding of the cone dystrophies in clinical practice. It should not be forgotten that cone dystrophy diagnosis can be done by careful anamnesis and detailed ophthalmologic examination as in many diseases.

Statement of conflict of interest: There are no conflicts of interest.
Sources of support if any: Nil.

\section{References}

1. Michaelides M, Hunt DM, Moore AT. The cone dysfunction syndromes. $\mathrm{Br} \mathrm{J}$ Ophthalmol 2004; 88(2): 291-297.

2. Simunovic MP, Moore AT. The cone dystrophies. Eye (Lond) 1998; 12(Pt 3b): 553565.

3. Langwińska-Wośko E, Szulborski K, Broniek-Kowalik K. Late onset cone dystrophy. Doc Ophthalmol 2010; 120(3): 215-218.

4. Hamel CP. Cone rod dystrophies. Orphanet J Rare Dis 2007; 2: 7.

5. van Schooneveld MJ, Went LN, Oosterhuis JA. Dominant cone dystrophy starting with blue cone involvement. $\mathrm{Br} \mathrm{J}$ Ophthalmol 1991; 75(6): 332-336.

6. Akça Bayar S, Şıngar E, Yılmaz G. Diffüz Fotoreseptör Distrofileri. Ret-Vit 2012; 20 : 243-249

7. Keunen JEE, Everdingen JAM van, Went LN, Oosterhuis JA, Norren D van. Color matching and retinal densitometry in patients and carriers of an X-linked progressive cone dystrophy. Arch Ophthalmol 1990; 108(12): 1713-1719.

8. Hartong DT, Berson EL, Dryja TP. Retinitis pigmentosa. Lancet 2006; 368(9549): 17951809.

9. Gözke E, Koçer A, Şafak N, Alanyalı A. Kon distrofisi: Optik disk solukluğunda düşünülmesi gereken bir tanı. İnönü Üniversitesi Tip Fakültesi Dergisi 2001; 8(4): 219-221.

10. Yung M, Klufas MA, Sarraf D. Clinical applications of fundus autofluorescence in retinal disease. Int J Retina Vitreous 2016; 2: 12.

11. Chiu CJ, Klein R, Milton RC, Gensler $G$, Taylor A. Does eating particular diets alter the risk of age-related macular degeneration in users of the Age-Related Eye Disease Study supplements? Br J Ophthalmol 2009; 93(9): 1241-1246.

12. Petriçli IS, Idil Merdogan A, Özen Tunay Z, Özdemir Ö. Herediter Retina Distrofili Olgularda Az Görme Rehabilitasyonu. Turk J Ophthalmol 2015; 45: 25-30. 